\title{
"Government in India and Japan is different from government in Europe": Asian Jesuits on Infrastructure, Administrative Space, and the Possibilities for a Global Management of Power
}

\author{
Markus Friedrich \\ University of Hamburg \\ markus.friedrich@uni-hamburg.de
}

\begin{abstract}
This paper investigates the influence of geographical distance on the practices and concepts of Jesuit administration in the early modern period. It discusses in particular select letters by Alessandro Valignano from East Asia, to demonstrate how loyal Jesuits in the Far East asked for administrative adjustments in order to overcome the enormous infrastructural difficulties involved in upholding constant epistolary communication with Rome. Valignano over and again stressed both the difference and the distance between Asia and Europe and thought that both factors necessitated an accommodation of the order's organizational framework. This case study thus helps address the broader questions of how the members of the Society of Jesus conceived of global space. It becomes clear that, while they hoped for institutional unity and insisted frequently on procedural uniformity, they also openly acknowledged that due to distance and cultural differences there never could exist an entirely homogeneous, single global Jesuit space.
\end{abstract}

\section{Keywords}

Asia - India - Alessandro Valignano - Jesuit administration - correspondence Claudio Acquaviva - superior general - visitor - periphery - communication 
In 16og, the great Jesuit theologian Francisco Suárez (1548-1617) declared the entire Society of Jesus ideally to consist of only "one nation and one province." He seemed to suggest that the field of Jesuit activities should be considered as one seamless, globally integrated, homogeneous space. If there were differences and distinctions, they should not affect Jesuit organization. Suárez was of course aware of the fact that the actual Jesuit order existed within a more fragmentized space. There was more than just one world-province. The spatial breakdown of the order's administration into distinctive units (provinces) had begun just a few years after the founding of the order in 1540. According to Suárez, however, the creation of provinces had been done for pragmatic reasons alone. It did not imply relinquishing a global or universal perspective. Regionalizing the Society's governmental structure was necessary due only to the "distance between [Jesuit] locations."

Suárez's statement highlights the relevance of spatial concepts for Jesuit self-understanding. Consciously, the order had incorporated different or even conflicting notions of geography and space into its own identity. On the one hand, official Jesuit documents time and again stressed the global nature of the order. The Constitutions proudly mention that the order is spread across the entire globe. ${ }^{2}$ Luke Clossey has recently produced a great deal of evidence detailing the global integration of Jesuit thought and activities. ${ }^{3}$ Such efforts were, in fact, so prominent that the possibility of overstretching missionary activities was a recurrent theme of Jesuit discourse. On the other hand, a contradictory approach to space was equally important for the order. "Being local" was another prominent strand within Jesuit thought. The Jesuits' willingness to localize their behavior has always been noted and even in its earliest days received considerable (often unwanted) attention. Their favorable stance

1 Francesco Suárez, "Tractatus decimus de religione Societatis Jesu in particulari," in Suárez, Opera omnia, editio nova, a Carolo Berton (Paris: Vives, 1877), 16:553-1159, here 1069: "Quia in Societate tanta est unitas, ut, quantum ad mutuum juvamen et affectionem omnium inter se, perinde reputanda sit, ac si esset una provincia et una natio. Quod enim multiplicentur provinciae, solum est propter necessitatem provenientem ex distantia locorum; in reliquis vero quantum ratio instituti postulat, servanda est maxima unitas et communicatio bonorum omnium, et mutuum auxilium, quoad fieri possit; unde fit ut Rectores et Superiores unius provinciae saepe ex alia provideantur, vel, e converso, ut qui in una est Superior, ad aliam mittatur, ut concionandi vel docendi munus exerceat."

2 Most famous is probably the brief, yet crucial opening-section of Part VIII of the order's Constitutions, see The Constitutions of the Society of Jesus, trans. George E. Ganss (St. Louis, Mo: Institute of Jesuit Sources, 1970), 316.

3 Luke Clossey, Salvation and Globalization in the Early Jesuit Missions (Cambridge: Cambridge University Press, 2008). 
towards accommodation and acculturation-i.e. towards localizing Catholic religion, liturgy, and life-style — has been well established. ${ }^{4}$

The ostensible contradiction between these two "spaces" of the Jesuit imagination - one globally integrated, one fragmented into a myriad of culturally distinctive regions-is the starting point for this article. ${ }^{5}$ I will explore just how the order simultaneously held notions of globally homogeneous and fragmented spaces and how early modern Jesuits negotiated the boundaries between the two. The article asks, more specifically, how Jesuits thought about regionalizing their administrative structures. If the order was willing to compromise in regard to culture, religion, and lifestyle, were they also willing to accept regional variation in governance? If the Jesuit mental map acknowledged regional varieties in culture and religion, was it also broken down into organizational fragments with hybridized and localized administrative institutions? Or, rather, did the Society of Jesus think that one institutional blueprint should (and could) fit everywhere on the globe? These are by no means esoteric questions, for in Jesuit thought the order's social unity depended crucially on its uniformity, and especially on uniformity in three areas: of doctrine, of ministries, and of government. The global implementation of a standard organizational framework was thus considered helpful in forging unity. Suárez's idea of a single Jesuit province covering the entire globe can be taken as a clear expression of this point.

Achieving institutional and administrative homogeneity across the globe, however, was difficult, or even impossible, as Jesuits openly acknowledged. A degree of organizational variation seemed inevitable, but needed to be negotiated. Jesuits all over the world therefore assessed carefully — and often critically — the advantages and disadvantages of the Roman headquarters'

4 Recent innovative work on accommodation as a practice — and less a principle-of the Jesuits in Europe and elsewhere include Ines G. Županov, Disputed Mission:Jesuit Experiments and Brahmanical Knowledge in Seventeenth-Century India (Oxford: Oxford University Press, 1999); Paolo Aranha, "Sacramenti o saṃskārāḥ?: L'illusione dell'accommodatio nella controversia dei riti malabarici," Cristianesimo nella storia 31 (2010): 621-46. Helpful is also Howard Goodman and Anthony Grafton, "Ricci, the Chinese, and the Toolkits of Textualists," Asia Major 2, no. 2 (1990): 95-148.

5 Similar issues are also helpfully discussed in Ines G. Županov, "Currents and CounterCurrents: Jesuit Geopolitics in Asia ( $16^{\text {th }}$ Century): A Commentary on Pierre-Antoine Fabre's 'Essai de géopolitique des courants spirituels: Alonso Sánchez entre Madrid, le Mexique, les Iles Philippines, les côtes de la Chine et Rome (1579-1593),'” in I gesuiti ai tempi di Claudio Acquaviva: Strategie politiche, religiose e culturali tra XVI e XVII secolo, ed. Paolo Broggio et al. (Rome: Morcelliana, 2007), 75-88. 
attempts to come to terms with global administration. ${ }^{6}$ To evaluate the ensuing discourse about governance, space, and power, this article draws mainly on Jesuit sources from India, Japan, and Southeast Asia. In particular, I will examine the letters of the well-known Jesuit Alessandro Valignano (1539-16o6), long-time visitor and provincial in the Asian missions between 1579 and 1606.7 It will become clear from this analysis that the Jesuits in Asia consciously and cautiously explored the distinctive administrative needs of extra-European provinces without ever abandoning their commitment to global administrative uniformity. 8

From a modern perspective, informed by theoretical and empirical sociologies of organization, Jesuit thinking about the impact of space and infrastructure upon institutions and organization might seem conceptually humble. Nevertheless, these debates should not be considered insignificant only because they did not lead to systematic theoretical and organizational thinking. For in essence we glimpse here some of the first European attempts to conceptualize globalization from an administrative vantage point. The Jesuits, like the Spanish and Portuguese empires before them, when trying to control the vast spaces of the newly "discovered" territories, at first intuitively relied on elements of social thought that had emerged over centuries, with the much smaller dimensions of European states and commonwealths in mind. Yet it soon become questionable if and to what degree European notions of social and political realities could still be meaningfully applied when the geographical spaces were altered so significantly. Indeed, Valignano and the other Jesuits that we will encounter - and many others besides them — were struggling almost daily

6 The highly critical memorialistas of Spain and Italy are discussed in Markus Friedrich, "Governing the Early Modern Society of Jesus: Concepts, Structures, Issues, and Critical Voices," Studies in Jesuit Spirituality 41, no. 1 (2009): 1-42, here 24-38. Important parallel discussions to the Asian cases in Mexico are now briefly mentioned by Fabian Fechner, Entscheidungsprozesse vor Ort: Die Provinzkongregationen der Jesuiten in Paraguay (1608-1762) (Regensburg: Schnell und Steiner 2015), 107, 111, 142.

7 On Valignano see M. Antoni Üçerler and Adolfo Tamburello, eds., Alessandro Valignano S.I.: Uomo del Rinascimento; Ponte tra Oriente e Occidente (Rome: Institutum Historicum Societatis Iesu, 2008). M. Antoni Üçerler, "Alessandro Valignano: Man, Missionary, and Writer," Renaissance Studies 17 (2003): 337-66. The classic reference is Josef Franz Schütte, Valignano's Mission Principles for Japan (St. Louis, Mo: Institute of Jesuit Sources, 1980).

8 On the Asian mission and its administrative development in general see Dauril Alden, The Making of an Enterprise: The Society of Jesus in Portugal, Its Empire, and Beyond, 1540-1750 (Stanford: Stanford University Press, 1996). Liam Matthew Brockey, The Visitor: André Palmeiro and the Jesuits in Asia (Cambridge, MA: Harvard University Press, 2014) deals with a slightly later period, yet his insights are also helpful for earlier developments. I think, however, that Brockey's very harsh critique of recent evaluations (particularly by Clossey, Salvation) of the Jesuits as "first global players" $(428-30)$ is going too far. 
to decide if and how such key concepts as uniformity, social coherence, obedience, compliance, or control could make sense if you were far away from $\mathrm{Eu}$ rope in Japan, India, or China. It needs to be stressed that these were issues that the Jesuits discussed initially not for their conceptual or theoretical importance but because their daily experience with the many practical difficulties in applying European concepts to an increasingly global organization forced them to. ${ }^{9}$ Their semi-explicit efforts to assess the structural difficulties of globalization were part of Europe's trial-and-error approach to developing technologies for managing global integration. Herein lies the historical significance of the cautious negotiation of administrative structures between Europe and Asia.

\section{India Is Different from Europe}

Jesuit administrators in the Far East regularly stressed how different India, Japan, or China were from Europe. ${ }^{10}$ Their letters expressed constant amazement about the incomprehensibility of the East from a purely European vantage point. The "diversity between these provinces and Europe" was a constant refrain in the correspondence. When Alessandro Valignano wrote a long survey of the Indian missions in 1580 , he started by mentioning that "this province of India is very different from all other European provinces, not only regarding climate and people, but also regarding religion, customs, and ways of living, and also with respect to our own lifestyle and pious ministries and establishments." The difference at times was so large, he continued, that "certain ways of acting that prove helpful in India are dismissed as inopportune in Europe."11

9 For a historical perspective on globalization, see David Held and Anthony McGrew, Global Transformations: Politics, Economics and Culture (Cambridge: Polity, 1999); Anthony G. Hopkins, "The History of Globalization—and the Globalization of History?, in Globalization in World History, ed. Anthony G. Hopkins (London: Pimlico, 2002), 11-46; Kevin H. O’Rourke and Jeffrey G. Williamson, "When Did Globalization Begin?," European Review of Economic History 6 (2002): 23-50; Jürgen Osterhammel and Niels Petersson, Geschichte der Globalisierung: Dimensionen, Prozesse, Epochen (Munich: C.H. Beck, 2007).

10 See also Joseph Francis Moran, The Japanese and the Jesuits: Alessandro Valignano in Sixteenth-Century Japan (London: Routledge, 1993), 29-41, where additional statements by Valignano are summarized.

11 Alessandro Valignano, "Sumario de las cosas que pertenecen a la provincia de la Yndia Oriental e al govierno della, compuesto por el Padre Alexandro Valignano visitador della, y dirigido a nuestro Padre General Everardo Mercuriano en el año de 1579," in Documentação para a história das missões do Padroado Português do Oriente, Índia, ed. António de Silva Rego, vol. 12 (1572-1582) (Lisbon: Agência Geral do Ultramar, 1958), 470-638, here 470-71: "En esta provincia de la Yndia Oriental Muy Reverendo en Christo Padre es tan 
During his thirty-two years of service in the region, Valignano continually insisted on the differences between the East Indies and Europe. Soon, however, he also began to highlight the fact that there were multiple cultures and sub-regions even within the vast Jesuit province of India. ${ }^{12}$ Just as India and Europe were hard to compare, so were Japan and India. In 1583 , for instance, he produced a long supplement to his 1580 report about India. This new memorandum dealt extensively with Japan, which Valignano had visited two years earlier. Now he focused on distinguishing Japan from both Europe and India. His reasoning followed the same logic as earlier: Japan is so distinct that "it is impossible [from afar] to understand the situation there and the necessary nature of the government that is required."13 The cultural fragmentation of the region made it impossible even for Jesuits living in Asia to understand more than one region properly. In 1585 , for instance, he declared Jesuits in Malacca incompetent in regard to the specific needs and context of the mission in the Moluccas. ${ }^{14}$ Time and again, Valignano emphasized that Europe and India, India and Japan, Japan and the Moluccas were hardly comparable. His abundant correspondence with the Jesuit curia in Rome repeatedly drove this point home. Juxtaposing Europe and India and insisting on their partial incommensurability became a key element of his reporting.

The differences both within Asia and between Asia and Europe had, according to Valignano and other leading Jesuits of the region, significant consequences for Jesuit administration. India was not like Europe and therefore "our government in India and Japan cannot be the same as in Europe."15 European

diferente de todas las otras provinçias de Europa, no solamente quanto al clima y gente mas tambien quanto a la religion, costumbres, modo de proceder y capacidad della, y finalmente quanto a los ministerios, casas y residencias y modo de vivir que aca tiene nuestra Compañia que puede facilmiente causar admiracion en los animos de aquellos que no tienen experiencia destas partes, por lo qual a las vezes puede nacer que lo que lo se haze muy açertado en la Yndia se juzgue en Europa por no tan bien acertado." Üçerler, "Valignano," 352-59 discusses Valignano's descriptions of Asian peoples, though he neglects to take into account the visitor's critical assessment of his own writings.

12 Valignano, "Sumario," 474.

13 Alessandro Valignano, Les jésuites au Japon: Relation missionnaire (1583); Traduction, présentation et notes de J. Bésineau, S.J. (Paris: Desclée de Brouwer, 1990), 54: "qu'on ne peut en aucune manière en comprendre la situation et la nature du gouvernement qui y convient."

14 Hubert Jacobs, ed., Documenta Malucensia (Rome: Institutum Historicum Societatis Iesu, 1974-84), 2:173-74 [hereafter Doc. Mal.].

15 Joseph Wicki and Georg Schurhammer, eds., Documenta Indica, 18 vols. (Rome Madrid: Institutum Historicum Societatis Iesu, 1948-88), 12:834 [hereafter Doc. Ind.] (Valignano to Acquaviva, October 28, 1583): "como el govierno de la India y de Japón es tan diferente del govierno de nuestros collegios de Europa.” 
laws and norms could not be followed or implemented there. ${ }^{16}$ The cultural and environmental fragmentation of the globe called for a parallel regionalization of governmental practices and routines. The specific administrative needs of India or Japan were, in fact, described by Valignano as being the very opposite of European requirements. Administrators who were thought to be reliable and apt in Europe were often found to be entirely useless in India and vice versa. ${ }^{17}$ Obviously, for Valignano, Jesuit superiors required varying qualities and abilities depending on where they were stationed.

For some Jesuits differences between Europe and Asia even appeared to invalidate the customary means for establishing a working relationship between Jesuit administrators in the field and their superiors. According to Jesuit administrative thinking, the order's headquarters in Rome and local or regional superiors were connected through regular correspondence. Ideally standardized letters went back and forth, keeping Rome up-to-date about the situation on the ground. This system of "lettered governance" required an enormous amount of trust in the written word. ${ }^{18}$ It relied on the assumption that letters were indeed able to convey relevant information and that writing could indeed adequately describe "the world." The order's headquarters in Rome thus "outsourced" direct observation and inspection to local agents and still claimed to be able to make meaningful decisions based on the observers' written descriptions.

From Valignano's vantage point, however, this basic assumption was somewhat naïve. He constantly wrote and described India for European Jesuits, yet his trust in the efficacy of his own letters and descriptions was sometimes shattered: "My frequent writing notwithstanding, many things about Japan cannot

16 Valignano, Jésuites au Japon, 116.

17 Doc. Ind., 12:834 (Valignano to Acquaviva, October 28, 1583): "Su modo de proceder es tan contrario al de Europa, muchas veses acontece que los que en Europa se julgan por muy actos [sc. aptos] para este guovernio, llegados aquí no salen y no son tenidos por proporcionados a juizio de todos; y otras veses, aunque más raras, los que en Europa parescían que no eran allá para tanto salen aquí para mucho."

18 See Ann Laura Stoler, Along the Archival Grain: Epistemic Anxieties and Colonial Common Sense (Princeton: Princeton University Press, 2009), passim, for the term "lettered governance," which she uses for nineteenth-century Belgian colonial administration. For more on Jesuit administration and letter writing see Markus Friedrich, "Communication and Bureaucracy in the Early Modern Society of Jesus," Zeitschrift für Schweizerische Religions- und Kirchengeschichte 101 (2007): 49-75; Friedrich, "Government and InformationManagement in Early Modern Europe: The Case of the Society of Jesus (1540-1773)," Journal of Early Modern History 12 (2009): 1-25; Friedrich, Der lange Arm Roms? Globale Verwaltung und Kommunikation im Jesuitenorden 1540-1773 (Frankfurt: Campus, 2011). 
be made understandable by letters." ${ }^{19}$ Although he tried as hard as he could to describe the wonders of Asia in his writings, he confessed that "occasionally I lack confidence in my ability to do so." 20 Speaking convincingly about Asia to someone who had no direct personal experience with the region was hard enough, but writing convincingly about Asia was, according to Valignano, particularly difficult. Occasionally, Valignano was unsure if he could make himself properly understood in Rome when portraying far-away lands. ${ }^{21}$ "Describing" seemed to be less a simple act executed by the writer of a letter but rather implied a lengthy process of conversation between Rome and Goa in order to determine the correct meaning of information: "Because of the difference and the distance it is impossible [for Rome] to take in everything completely with the first sip," he wrote once, and went on to correct Roman misunderstandings of his earlier writings. ${ }^{22}$ This was a far cry from the simple assumption undergirding the Jesuit system of correspondence that letters were unambiguously able to inform and describe.

Stressing the indescribable nature of India and Japan was occasionally a tactical move. On several occasions, Valignano wished to return to Europeand the ostensible necessity for personal conversations with the Jesuit general, the pope, or the Spanish-Portuguese king in order to inform them about India presented a convenient argument. But there is more to Valignano's nuanced assessment of the value of written information. His partial skepticism towards the potential of "lettered governance" is connected to a broader debate in early modern Europe about the relative status of oral and written, first-hand and second-hand information. The history of early modern production of knowledge and management of information can be at least partially described as a struggle to assess, clarify, and secure the epistemological status of written information. This process was particularly acute in the case of information that came from far-away lands and was not backed by personal contact and oral conversation. Because the Society of Jesus is generally—and

19 Doc. Ind., 12:833: "Porque por mucho que se escrive no se puede bien dar a entender."

20 Doc. Ind., 14:93 (Valignano to Acquaviva, December 17, 1585): "Porque en la verdad senpre deseé mucho assí con V.P., como con la santa memoria del Pe. Everardo, de dar perfecta noticia de las cosas desta Provincia. Y aunque he trabayado y trabayaré mucho en esso, alas vezes me vyene huna manera de desconfiança de poder alcançar lo que deseo, por seren las materias muchas y muy diversas de las de Europa, y que se entienden bien de muy pocos, quantos menos se dexarán bien entender por cartas."

21 Valignano, Jésuites au Japon, 55, 116.

22 Doc. Ind., 14:209: "Mas porque por la gran destancia de los lugares y deversidades de las cosas, no se pueden todas en un golpe bien apurar, trataré en nésta por parecer de la consulta acerca de algunas pocas que nos hazen aquí ahún dudar." 
rightly - considered to be a champion of written communication, it needs to be stressed all the more that a certain uneasiness with the generals' seemingly limitless trust in written representations of far-away events and circumstances was occasionally criticized even by their most trusted exponents. ${ }^{23}$

\section{India Is Distant from Europe}

While Jesuit governance in India required special attention because of general differences between Asia and Europe, the geographic distance between the two areas was an even greater factor. ${ }^{24}$ Valignano and his associates in Asia stressed that the slow movement of letters made tight control of India by Rome entirely impossible. ${ }^{25}$ If communication between India and Europe took months and years, this clearly had an impact on the practicalities of government. The Jesuits were not shy to acknowledge the inverse relationship between geographic distance and administrative efficiency: "Experience shows that this province cannot be governed by letters and requests sent from India and answered by Rome, because it takes too long and a myriad of circumstances and vicissitudes alter the status quo before we have an answer," as one prominent Jesuit stated. ${ }^{26}$

The constraints imposed by early modern infrastructure was of course most obvious from a global perspective. Yet even within Europe Jesuits acknowledged that geographic distance and infrastructural impediments limited the possibilities for Rome to manage local affairs. The infrastructural complications of Indian government differed from the intra-European problems in scale

23 See now also Fechner, Provinzkongregationen, passim for more on oral communication within the Society of Jesus. See also Josef Wicki, "Die ersten offiziellen mündlichen Berichterstattungen in Europa aus den überseeischen Missionsgebieten der Gesellschaft Jesu (a. 1553-1577)," Neue Zeitschrift für Missionswissenschaft 14 (1958): 152-66.

24 Moran, Valignano, 42-44 provides details about shipping and the reception of letters. See also Paul Nelles, "Cosas y cartas: Scribal Production and Material Pathways in Jesuit Global Communication (1547-1573)," Journal of Jesuit Studies 2, no. 3 (2015): 421-50 (doi: 10.1163/22141332-00203003).

25 See e.g. Doc. Ind., 12:393-94 (Nuno Rodrigues, Rector of the College in Goa, to Acquaviva, November 7,1582$)$.

26 Doc. Ind., 12:441 (Georgus de Carvalhal, Consultor, to Acquaviva, October 10, 1581): "Ad Tuam R. Paternitatem ex obligatione scripturo multa occurrebant, sed experientia omnes docuit hanc Provinciam non posse administrari literis et quaestionibus ex India missis et Roma responsionibus expectatis, quia sero medicina paratur, et sunt propemodum infinitae rerum vicissitudines et circunstantiae quae casum quaesitum ante responsionem mutant." 
rather than in principle. In 1547, for instance, Ignatius of Loyola (c.1491-1556) himself wrote the following to Jesuits in Gandía, Spain:

Experience is now showing us that it is impossible to make provision from here [Rome] for many important things. This is partly because one cannot write and let us know everything (not everything can be confided in writing), and partly because often the time for making a decision runs out while people are asking our opinion here and we are sending a reply. ${ }^{27}$

Thus, even within Europe the practical limitations that infrastructure placed on governance were considerable. Centralization of power in Rome could not mean total micro-management from headquarters, as Ignatius openly acknowledged. To the contrary, the Jesuits consciously adjusted their general preference for a strong center in Rome with accommodating it to infrastructural realities.

One of the most telling consequences of this realistic insight into the infrastructural impossibility of "total centralization" was a careful scaling of the rhythm of correspondence according to geographical distance from Romethe closer to Rome, the more frequent and more intense communication was to be, the further away from Rome, the more infrequently (but still regularly) should letters be sent. ${ }^{28}$ The architects of the Jesuits' communicative network understood from early on that high-frequency communication was meaningful only where the time of transmission was short-which in pre-modern times meant that distances had to be short. Where distances were long and communication took months or years, however, fast-paced epistolary attempts at central control were self-defeating. Valignano and the Jesuits in the missionary field understood this clearly. But what needs to be stressed even more is that the Jesuits in Rome, starting from Ignatius and Polanco, also understood this very well. The generals and their aides freely acknowledged that Roman micro-management of local affairs was most often simply impossible. Centralization was thus attenuated from the start by the acceptance of infrastructural shortcomings.

27 Ignatius to the Jesuits at Gandía, July 29, 1547, quoted in Joseph A. Munitiz and Philip Endean, eds., Saint Ignatius of Loyola: Personal Writings; Reminiscences, Spiritual Diary, Select Letters including the Text of the Spiritual Exercises (London: Penguin, 1996), 186.

28 Details in Friedrich, Der lange Arm Roms, 61-63. Markus Friedrich, "Circulating and Compiling the litterae annuae: Towards a History of the Jesuit System of Communication," Archivum historicum Societatis Iesu 77 (2008): 1-39. See also Nelles, Cosas y cartas. 


\section{Adjusting Government for Difference and Distance}

The construction of Asia as both different and distant from Europe ultimately led to demands for administrative adjustments. ${ }^{29}$ Asian Jesuits tried to remedy the administrative impasses by requesting procedural and institutional alterations on several levels. At times, their ideas went in surprising directions. Strikingly un-modern, for instance, is the occasional tendency towards conscious administrative self-marginalization. Strident insistence on the special circumstances of India led to voluntary disenfranchisement. This is particularly obvious in the debate of 1586 whether India should send an envoy to Rome every three years to participate in the congregation of procurators. In theory each Jesuit province dispatched two of its members to Rome for the occasion to discuss points of common business and to inform headquarters about the current state of affairs in the provinces. The meetings of the procurators played an important part in Jesuit life, not least because they had the power to call extraordinary general congregations. Valignano, however, did not see much merit in the participation of the Jesuits from the Indian province: "Since this province is so far from Europe, in no way can we understand whether the current situation calls for a general congregation or not." 30 The informational asymmetry between Asia and Europe was thus reciprocal: Europe knew little about Asia,

29 See also the pertinent remarks in Tobias Winnerling, Vernunft und Imperium: Die Societas Jesu in Indien und Japan, 1542-1574 (Göttingen: Vandenhoeck und Ruprecht, 2014), 63-65.

$30 \quad$ Doc. Ind., 14:348: "porque la principal cosa por la qual se embían de todas las Provincias procuradores a Roma a la Congregación de los procuradores, es para embiar cada Provincia su parecer acerca de haverse hazer o no congregación general, y como esta Provincia está tan remota de Europa, en ninguna manera puede entender los negocios en tal modo que se pueda determinar si conviene o no hazerse congregación general, y assí parece que queda en esta Provincia excluydo el fin principal que pretende la Compañía en la yda desta procurador." Other Jesuits in India thought more positively about the sending of procurators - yet it is remarkable that they, too, were unable to imagine a genuinely Indian contribution to such a meeting. According to them, sending a procurator was important since, although Valignano's point was well taken, such an envoy could rely on advice given him by other (most likely European) members of the congregation of procurators. See Doc. Ind., 14:349: "aunque es verdad que en esta Provincia no hay tanta información de lo que passa en Europa, que se pueda bien determinar si conviene hazerse general congregación o no, todavía este procurador, quando fuere a Roma y oyere las razones que de todas las más Provincias dieren los más procuradores, se podrá muy bien determinar como todos los otros a dar su voto." On later procurators going to Europe, especially in the seventeenth and eighteenth centuries, see Charles E. O'Neill and Joaquín María Domínguez, eds., Diccionario histórico de la Compañía de Jesús (Rome-Madrid, Institutum Historicum Societatis Iesu-Universidad Pontificia Comillas, 2001), 2:2000-1. 
and Asia knew little about Europe. Accordingly, Valignano was content with a peripheral position for India, at least for the moment. He indulged in a form of self-isolation-and clearly missed the point: one of the ideas behind the congregation of procurators was that all provinces should state if they, "due to reasons and causes from their own provinces," thought a general congregation necessary. ${ }^{31}$ The idea that the Indian province of its own accord might have any interest in such a general assembly did not cross Valignano's mind. By stressing the distance and difference between Europe and Asia, he thus withdrew India from the order's decision-making process.

Valignano probably lacked interest in the congregation of procurators because of practical considerations. Sparing trustworthy missionaries for the trip to Rome was a tough choice for an administrator who constantly complained about the lack of manpower. Maybe he was also simply realistic in predicting little more than a marginal role for Indian procurators in Rome. Nevertheless, it is remarkable that Valignano was willing to give up one of the very few possibilities to influence Roman decision-making. He seemed to have been largely content with focusing on the tasks ahead within the region. Providing India with institutional influence in the Society of Jesus was certainly not his top priority in $1586 .{ }^{32}$

Valignano's reluctance to send procurators, however, does more than reveal his skeptical resignation concerning India's influence in global Jesuit decisionmaking. From a more regional perspective, this was just another step towards adjusting the Jesuit institutional and governmental framework to situations different from Europe. Valignano's dislike of the election of Indian procurators (which in theory required summoning a provincial congregation) followed logically from his customary skepticism towards Jesuit assemblies in Asia in general. Given the Indian province's vastness, he claimed, even provincial congregations could and should have a different role than in Europe. ${ }^{33}$ Normally,

31 See for instance the clear statement by Acquaviva to the province of Milan, May 6, 1584, in Bayerisches Hauptstaatsarchiv Munich, Jesuitica 16, unfol.: "[81] Statuere in qualibet congregatione provinciali, an habenda sit generalis, nec ne, non pendet ab informationibus, quae possent haberi extra provinciam, sed ex causis et rationibus, quae occurrunt in propria provincia; quia quae aliunde habentur, non possunt sciri sufficienter, sicuti requirit resolutio tanti mometi."

It should be mentioned that Jesuits in other non-European regions saw things different. On the Spanish-American Jesuits' eagerness to be represented appropriately, see Fechner, Provinzkongregationen.

The decisions of the Indian provincial congregations are summarized in Josef Wicki, "Die Provinzkongregationen der Ordensprovinz Goa 1575-1756: Ein geschichtlicher Überblick," Archivum historicum Societatis Iesu 58 (1989): 209-77. 
the most important Jesuits of a province would meet every three years to discuss current affairs and elect the procurator going to Rome for the congregation of procurators. But in India (and in Japan after it became a vice-province in 1583) summoning missionaries was neither easy nor advantageous, according to Valignano.

A first difficulty lay in the enormous dangers of travel in Asia. Going to Goa, for instance, was complicated and, in Valignano's eyes, a provincial congregation was not necessarily worth the effort. More fundamentally, the distance from Rome and the delay in communications seemed to prevent the provincial meetings from fulfilling most of their basic functions. Many decisions taken by the congregation required Roman approval. Yet as approval from Rome would be received only after several years of waiting, the congregation's decisions and discussions would and could never have any practical impact and were consequently superfluous. ${ }^{34}$ While provincial congregations could not be entirely abrogated, Valignano preferred other means of decision-making. His fellow Jesuits in India mostly agreed. In 1583 , the second provincial congregation of India asked Rome to abolish the requirement of triennial meetings and instead allow for a much more casually organized "consultation." 35 In 1586, it was suggested that a provincial congregation be held every six years, a period later extended to nine years. ${ }^{36}$

The slowness of communications required still other adjustments to the mechanisms of Jesuit government. Since it was usually impractical to wait for detailed decisions from Rome, Indian Jesuits requested an extended range of authority under canon law (facultates) for their regional and local superiors. Concerning the Japanese vice-provincial, for instance, Valignano thought "that the pope should give him authority to dispense from all obligations under canon law, to publish whatever he deems acceptable."37 The Indian provincial Rui Vicente (1523-87) asked in 1581 for the right to allow all local superiors the consecration of chalices and altars so that they need not have recourse to bishops or to him. After some negotiation, the general eventually granted Vicente the extended facultas, just as he followed the recommendation to broaden the

34 Valignano, Jésuites au Japon, 221-22.

35 Doc. Ind., 13:324.

36 Six years: Doc. Ind., 14:345-47. A slightly more ambivalent statement about the procurator is in Doc. Ind., 15:295 (Valignano to Acquaviva, July 24, 1589). Nine years: Wicki, "Provinzialkongregationen," passim.

37 Valignano, Jésuites au Japon, 193. 
privileges of superiors in India. ${ }^{38}$ The range of provincial authority was thus expanded in reaction to the impossibility of direct and detailed Roman control.

Valignano's awareness of infrastructural limitations to Roman governance in India also surfaces in his rather nonchalant attitude towards instructions sent from Rome. He did of course accept that the general's more-or-less absolute authority extended to Asia. Yet, the relative lack of knowledge and understanding of India in Europe, combined with difficult and time-consuming patterns of communication, seemed to suggest and even require a rather liberal approach to instructions from Rome in daily life. The possibilities for a "creative reading" of Roman instructions were generally much enhanced by the slowness of communications. ${ }^{39}$ More importantly, even open disregard for Roman instructions came to be considered an acceptable practice in Asia. To be sure, even in Europe, where communications were considerably faster, Roman instructions were often made conditionally—that is, they specified that they did not have to be followed if local circumstances had changed to such a degree that the basis for the decision from Rome was no longer valid. ${ }^{40}$ On similar grounds, though with greater frequency, Indian superiors questioned the generals' orders. Valignano and other superiors in India at times openly disregarded explicit instructions. On December 12, 1583, for instance, Valignano wrote an entire "report on things that we have done differently from the orders given by Father Everard [Mercurian] and by you [i.e. Acquaviva] this year."41 This was possible since Valignano had received an explicit authorization to deviate from the general's express orders if necessary. To make sure that such adjustments did not raise general questions about the general's authority, Valignano legitimized his liberal interpretation of Roman orders by stressing that obviously headquarters was insufficiently informed—had the curia only

38 See Doc. Ind., 12:339, 691-92. Certain faculties, however, were not granted, for instance the authority to dismiss professed of four vows, see Wicki, "Provinzialkongregationen," 299 (Provincial Congregation 1599). See also John Humbert, "Some Answers of the Generals of the Society of Jesus to the Province of Goa," Archivum historicum Societatis Iesu 36 (1967): 72-109, here 83-84: General Gianpaolo Oliva (in office, 1664-81) held a more restricted view of certain facultates. See also Doc. Ind., 13:847 and 14:209-17.

39 See the discussion in Županov, Disputed Mission, 69-74. See also Županov, “Currents," 88.

40 Interesting remarks on this point can be found in Dionigi Spanu, Inviati per l'edificazione: Spiritualità delle istruzioni apostoliche di S. Ignazio; Rapporto con le Costituzioni della Compagnia di Gesù e ispirazione evangelica (Rome: Pontificia Universita Gregoriana, 1977).

41 Doc. Ind., 13:392-404: "relación de algunas cosas que se hizieron diferentemente de lo que N.P. Everardo, de sancta memoria, tenía ordenando y aun de lo que V.P. ordenó este año." 
"understood what was going on, it would have changed its mind."42 Valignano's claim for partial regional autonomy was therefore somewhat tautological: since he was unable to properly inform Rome, given the insufficiency of letters and the slowness of transport, Rome was likely to misapprehend the situation on the ground and thus could not really expect its orders to be taken literally. Informational inaccessibility, infrastructural isolation, and semi-autonomous decision-making were closely related and mutually self-enforcing. Nonetheless they were not cast as an open attack on the established structures of power.

The tendency to call for considerable independence is particularly obvious in India's request for a "second general" in the region. ${ }^{43}$ Safeguarding a functional administrative hierarchy in India meant shortening communications. In order to do so, some Jesuit office-holder in Asia should take over most of the general's tasks. In 1581, for instance, Nonnius Rodrigues (1539-1604), rector in Goa, suggested that Acquaviva send a trusted aide and invest him "with all your spirit and power."44 In 1590, Valignano also thought that "small generals" were necessary and should take over supreme authority in India. ${ }^{45}$ This was a highly ambivalent idea, however. On the one hand, strong regional authorities ("commissaries") had played a key role in the early years of the Society of Jesus. ${ }^{46}$ Valignano's request could therefore claim some historical pedigree. On the other hand, by the late sixteenth century the idea of adding strong regional leaders had acquired anti-Roman overtones. Spanish Jesuits who were unsatisfied with Acquaviva's tenure and opposed the broad shift of the order from a Spanish to a more Italian outlook adopted the idea of installing a Spanish commissary. He was quasi independent from Rome in order to advance Iberian perspectives and interests. ${ }^{47}$ Given this context, it is highly significant

42 Doc. Ind., 13:590 (Valignano to Acquaviva, December 12, 1584): "Quanto a la facultad que V.P. da al Provincial de la India, de poder suspender o mudar los órdenes que de Roma vinieren con la consideración que V.P. encomienda, espero que quanto a lo que a mí toca no avrá desviar de la intención de V.P., sino quando la cosa obligare de tal manera que se entienda que V.P., se supiesse lo que passa, mudaría parecer."

43 See Doc. Ind., 16:26 (Juan de Salanova, Punnaikayal, to Acquaviva, December 16, 1592): "otro $2^{\circ}$ General $[. .$.$] por la grande distancia con que dista de V.P. { }^{\text {" }}$

44 Doc. Ind., 12:393-94 (Rodrigues to Acquaviva, November 7, 1581): "transfunda en el todo su spíritu y poder."

45 Doc. Ind., 15:510 (Valignano, Nagasaki, to Manuel Rodrigues, Rome, October 14, 1590): "geral pequeno."

46 Guy Philippart, "Visiteurs, commissaires et inspecteurs dans la Compagnie de Jésus de 1540 à 1615," Archivum historicum Societatis Iesu 37-38 (1968-69): 3-128, 170-291.

47 See, e.g., Michela Catto, La Compagnia divisa: Il dissenso nell'ordine gesuitico tra '50o e '6oo (Brescia: Morcelliana, 2009). 
that Acquaviva largely acquiesced to Valignano's request. This shows, yet again, that the Society of Jesus was highly sensitive to the needs to accommodate its organizational structure to infrastructural necessities.

The details of this "second general" idea proved contentious. There were by that time two institutional contenders, the provincial and the visitor. While the former was an ordinary administrative position within the Society of Jesus, the latter normally was an extraordinary envoy sent for a short time by Rome to inspect local policies. In India and the Far East, however, and especially under Valignano's tenure, the position of visitor became quasi perpetual. This development aroused considerable tensions in Goa. Over the years, an articulate opposition formed against Valignano. The debate about adequate institutional arrangements for India thus became entangled with a more personalized conflict about Valignano's style of governance and personality. ${ }^{48}$ Nevertheless, the institutional alternatives clearly emerge from the sources. Valignano, on the one hand, lobbied for a strong and quasi-perpetual visitor. In his long treatise on India from 1580 , he devoted a separate chapter to this point and asked that the visitor be given extraordinary faculties, including the right to remove and replace provincials. ${ }^{49}$ The second Indian provincial congregation of 1583 followed his ideas and asked that a visitor should always be present in Asia. ${ }^{50}$ Later in his career, too, Valignano was still recommending a "quasiordinary" visitor. ${ }^{51}$

Indian Jesuits critical of Valignano, however, stressed how unusual and detrimental a perpetual visitor could be. Francisco de Monclaro (1531-95), one of his most outspoken opponents, insisted on this point in a bitter letter to Acquaviva from October 1593. Acquaviva's willingness to allow the visitor of India (i.e., Valignano) to become a second general was, according to Monclaro, "scandalizing" the Jesuits, because they understood this unusual institutional arrangement as a show of mistrust. Monclaro summarized his opposition to Valignano and to perpetual tenure of visitors when he declared to Acquaviva: "We only want you as our general and no one else and all our orders should

48 He displayed some haughty behavior and seemed openly to consider himself of particular importance; see the accusations by Jerónimo Rebelo, Doc. Ind., 14:288-90 (to Acquaviva, January 13, 1586), and Valignano's own admittance Doc. Ind., 14:735-36 (to Acquaviva, December 6, 1587).

49 Valignano, "Sumario," 568.

$5^{0}$ See the requests by the congregation and Valignano's additional letter to Acquaviva (December 13, 1583) in Doc. Ind., 13:326, 438.

$5^{1} \quad$ Ibid., 13:816: "Visitador quasi ordinario." 
henceforth come from Rome."52 Others followed suit and-in what seems to have been a well-organized campaign — sent similar complaints to Acquaviva. ${ }^{53}$ Monclaro and his followers thus articulated their criticism of Valignano by reassessing the power relations between India and Rome. In order to end the current visitor's tenure, they aligned themselves with a more traditional and more Rome-centered interpretation of Jesuit governance. The infrastructural and practical considerations undergirding the claims for a perpetual visitor were, in their presentation, trumped by a more literal application of the order's institutional framework.

There was yet another dimension to the debate about the merits of having a quasi-perpetual visitor. Besides standing in for the distant general, a perpetual visitor could also help overcome the problems caused by the vastness of the Indian province. As was obvious to all Jesuits in Asia, the provincial residing in Goa was in no position to visit far-flung outposts personally. Personal inspection, however, was normally considered one of the most important aspects of the office. While the order's central government in Rome relied almost exclusively on lettered governance and declined all calls for first-hand inspection, the office of provincial was founded on the very opposite principle: provincials were thought to rely particularly on their own inspection in their governance. Office holders were thus usually required to tour their province and visit all Jesuit establishments annually. Responsible for the entire region of modern-day India, Indonesia, Japan, and China, however, such an undertaking was altogether impossible for the provincial in Goa. Contrary to standard Jesuit administrative logic, thus, even the internal government of the Indian province had to rely on lettered governance. ${ }^{54}$

52 Ibid., 14:186: "Estaa esta Provincia mui sentida y de un cierto modo mui escandalizada de V.P., en la querer governar por tan differente modo de lo que govierna las otras Provincias de la Compañía y tan extraordinario [...] solamente queremos a V.P. por nuestro General y no a otro, y las reglas, avisos y regimientos que vienen de Roma [...]." Monclaro was very critical already in 1583, see Doc. Ind., 12:862-63.

53 See e.g. Doc. Ind., 16:407 (Gomes Vaz, Goa, to Acquaviva, November 21, 1593). In this letter, Vaz accuses Acquaviva of not trusting the Indian province. See ibid. 641-46 the documents of the third Indian provincial congregation that asked to recall Valignano. Acquaviva, however, mostly stood by his trusted visitor and reprimanded the Indian Jesuits accordingly. The confusion became even greater when Valignano had to resign his office of visitor for India in 1595 and it was unclear which position he should hold from then on-was he the vice-provincial of Japan or "visitor for Japan and China"? See Üçerler, "Valignano," 350 with more details.

54 Several statements by Valignano describe how much the provincial of India was forced to govern by letters and how this differed from what provincials were normally 
One solution of this dilemma was to delegate the inspection of Jesuit establishments to the visitor. The visitor, according to Valignano, helped localize governance. He provides a forceful description of how Jesuit governance at the regional level was meant to function and how this could be achieved in India:

For this province to be well governed it seems to be necessary that regular visits should occur from the governing head. He should himself observe major differences and the special circumstances of all places and of all Jesuits with his own eyes. Since neither the provincial nor any other superior can do this, however, they will never have proper and truthful experience of their province and will never be able to know what is going on in all the different parts of it. All of them will always only know what happens in their vicinity and will constantly be concerned only about their own benefit. Because of all this it seems expedient that a visitor or commissary should be established to gain the required experience. ${ }^{55}$

This passage clearly states that the largely European institutional logic evident in the Constitutions and subsequent norms could not be simply transferred to India. Accordingly, Valignano suggested a creative application of the visitor's office to overcome the administrative impasse. Yet there were more options available to make the vast region of Asia more governable. The most obvious solution, besides establishing a visitor, was some sort of division of labor. In 1585 , for instance, the provincial of India was granted an exception from the duty to visit every establishment personally. Acquaviva ruled that the

supposed to do. Valignano consequently also stressed how ill equipped Goa was for this huge bureaucratic operation. On several occasions he helped institutionalize a provincial "secretariate" that was seen as a somewhat unique and unusual feature specific to Indian government. See Doc. Ind., 13:392-95; 16:51. See also Doc. Mal., 2:193-96. A hostile thrust against Valignano based on his reliance on letters by Monclaro can be found in Doc. Ind., 16:192.

55 Valignano, "Sumario," 555-56: "Para ser aquella provincia bien governada pareçe necessario que la cabeça principal que la govierna la visite y tenga verdadero concepto de vista de toda ella conociendo la differencia y las qualidades de todos los lugares y de los subjectos que ay en ella, y como esto no lo puede hazer el provincial y los otros superiores, aunque visiten las partes que estan debaxo de su jurisdicion, no saben lo que passa en las otras partes, ni ellos pueden tener verdadera y universal informacion de la provinçia ni la pueden dar a su provincial, porque como cada uno dellos no sabe por experiençia sino solo lo que passa en las partes que govierna y es movido del proprio objecto que vé y de la carga que tiene [...] y para tener este conocimiento universal, parece que es neçessario un visitador o comisario para tener este conocimiento el qual sea ordinario." 
provincial in Goa could very well ask someone else (and emphatically not the visitor) to travel in his stead to distant regions. ${ }^{56}$

Fragmenting the Indian province into several smaller administrative entities of equal standing was yet another possibility. Breaking up "India" into two or three (vice-)provinces might help with governance. ${ }^{57}$ There had been considerable scheming as to how this might best be done. Valignano suggested in 1577 the establishment of a vice-province for the Moluccas and Japan together. ${ }^{58}$ As he came to know the region better, however, he realized that Japan and the islands of Southeast Asia could not be governed together by one person. A more nuanced structure would be necessary. ${ }^{59}$ Consequently a Japanese viceprovince was created in 1583 that also covered China but no regions further south. ${ }^{60}$ Although the relationship between the vice-province and the provincial of India remained ambivalent for some time, ${ }^{61}$ this ultimately proved to be an effective arrangement.

More complicated was the situation further to the south in the Moluccas. Equally hard to reach from Goa as Japan, the administrative challenges here were huge. Should not another vice-province be created for Malacca and the Moluccas? Valignano, who was initially supportive, soon expressed reluctance towards creating a semi-autonomous southern administrative region. Rome agreed. ${ }^{62}$ Jesuits in the field, however, continued to demand a superior capable of making important decisions closer to home than Goa. At the very least the superior in nearby Malacca should be granted some authority in urgent matters: ${ }^{63}$ "Otherwise it is impossible to receive answers to important

56 Doc. Ind., 16:153 (Acquaviva to Valignano, December 24, 1585).

57 A very brief but helpful exposé can be found in O'Neill and Domínguez, Diccionario, 2:200-1.

$5^{8} \quad$ Doc. Mal., 2:4-6.

59 Ibid., $2: 81-82$.

6o For the problems arising from the combination of Japan and China under one authority and for the eventual break-away of China as independent vice-province in 1619 see Liam Matthew Brockey, Journey to the East: The Jesuit Mission to China 1579-1724 (Cambridge, MA: Harvard University Press, 2007), 65-66, 73-77.

61 See e.g. Valignano's comment to Acquaviva that the vice-province of Japan could not be governed by India except "con una manera de superintendencia muy superficial," Doc. Ind., 16:93 (January 12, 1593). This vague statement highlights how complicated it was to combine regional autonomy and institutional hierarchies.

62 Doc. Mal., 2:136-39.

63 Ibid., 2:147 (Letter from Bernardo Ferrari, Ambon, to Acquaviva, May 14, 1584). 
requests within two years, or even three or four years if ships get lost."64 No such reorganization of southeast Asian administrative space was forthcoming, however, and Jesuits in the Islands of Malacca complained repeatedly about the lack of a nearby superior who had direct knowledge of local circumstances. Letters were again considered an inadequate basis for decision-making whether in Goa or Rome. Letters were only "dead reporters," one Jesuit claimed, and not able to replace first-hand knowledge. ${ }^{65}$ Once more, Jesuits in Asia articulated explicit skepticism towards the powers of written descriptions as the sole basis of government. Such complaints eventually enticed Valignano to dispatch a special envoy, Antonio Marta (d.16og), who served as "visitor." Marta himself soon openly endorsed the Moluccas Jesuits' quest for a local authority with the title of vice provincial. ${ }^{66}$

Further debate ensued before the province of Malabar was finally established in 1605 . There is no need to follow the twists of this discussion herethe basic points are obvious from the glimpses offered so far. It was thought that fragmentation of the vast Indian province would increase the efficiency of Jesuit government. The Jesuits thus not only contemplated adjusting the order's institutional framework to space and geography, they also considered adjusting their administrative geography to fit their customary institutional framework. Making personal visitation by provincial, vice provincials, or other "universal superiors" a practical possibility was a major concern for Jesuit thought about effective administration across geographic space. ${ }^{67}$

64 Doc. Mal., 2:164 (P. Nunes, Tidore, to Acquaviva, April 27, 1585): "Porque de otra manera no podemos tener respuesta de lo que es necessario sino en espacio de dos años, y si la nave arriba o se pierde, como de ordinario acaesce, después de 3 y 4 años." A similar letter went out to the Portuguese assistant in Rome, Melchior Rodrigues, Doc. Mal., 2:168.

65 This striking expression occurs in a strong-worded letter by Pero Nunes, Ambon, to Acquaviva, June 5, 1587, Doc. Mal., 2:211: "Cuya causa total pienço yo ser no se visitar nunqua por los Provinciales de la Yndia ni Visitadores que V.P. de Europa ynbía, y terse como cosa desmenbrada, de lo que se sigue no sólo la christiandad ser la que es, may aynda entre los nuestros aver grandes naufragios, por se veren tan remotos y desenparados de la providencia del Superior. Porque los que vienen a visitar por mandado del e se queden acá. Y por más que se escriva, nada provecha[,] por la carta ser relatador muerto y que no exeprime al bivo [sc. vivo] lo que honbre siente, y portanto mueve tan poco y se iscreve con tan pouco fructo."

66 Doc. Mal., 2:213-14.

67 There were limits to pragmatism, however. From a purely geographical perspective, Malacca would best have been associated with the growing Jesuit community in Manila. Since the Philippines belonged to Spain and India to Portugal, however, no such connection was possible. Factors beyond expediency and Jesuit practicalities clearly determined the actual outcome of Jesuit governmental structures to a great degree. In fact, the 


\section{Personalizing the Problem}

Ann M. Carlos and Stephen Nicholas have discussed similar problems of early modern trading companies in a series of important papers. ${ }^{68}$ According to their studies, the companies designed their institutional framework especially to "control managers at a distance" in "situations of incomplete information and uncertainty." Like the trading companies, the Society of Jesus invented a great many technologies to control the administrative performance of local and regional superiors. Correspondence, for instance, was solicited from a multitude of local agents in order to compare different accounts and thus more effectively control the situation on the ground. A strict regime of control, however, was not the only means applied by the Society of Jesus to solve its "agency problem." Lacking the trading companies' option to use financial incentives to solicit compliance, the Jesuit relied on a different strategy: they personalized the problem of securing local compliance by tying it to the organization's overall interest. ${ }^{69}$ Besides perfecting mechanisms of control, the Jesuits wished to "perfect" their local agents. If the right people governed, the Jesuits claimed, the "agency problem" would be more easily confronted. Being able to trust local agents, therefore, was of the utmost importance. ${ }^{70}$ Assessing the superior's personal qualities was key to this approach.

competition between Spain and Portugal in Asia had an impact on the Jesuit structures of government elsewhere, too. Promoting the vice province of Japan to the status of province, for instance, seemed unfeasible since this would diminish Portuguese influence and open Japan to the Spanish Jesuits in Manila, see Doc. Ind., 16:643.

68 See especially Ann M. Carlos and Stephen Nicholas, "Managing the Manager: An Application of the Principal Agent Model to the Hudson Bay's Company," Oxford Economic Papers, n.s. 45 (1993): 243-56, where all quotes in the text come from. See the critical response to this approach by S.R.H. Jones and Simon Ville, "Effective Transactors or RentSeeking Monopolists? The Rationale for Early Chartered Trading Companies," The Journal of Economic History 56 (1996): 898-915 and the answer by Ann M. Carlos and Stephen Nicholas, "Theory and History: Seventeenth-Century Joint-Stock Chartered Trading Companies," The Journal of Economic History 56 (1996): 916-24. For more on the authors' approach see also Ann M. Carlos and Stephen Nicholas, "Giants of an Earlier Capitalism: The Chartered Trading Companies as Modern Multinationals," Business History Review 62 (1988): 398-419.

69 See also Carlos and Nicholas, "Managing the Manager," 253-55.

70 Trust (or "confidence") in local superiors as crucial feature structuring the relationship between Rome and a semi-autonomous provincial in India was particularly stressed by Nonnius Rodrigues in a letter to Acquaviva from November 7, 1581, Doc. Ind., 12:393-94. See also Brockey, Journey, 79 for an interesting discussion of similar developments in 
The Jesuits thus developed a moral and spiritual solution for the organizational problem. Raising moral, religious, and intellectual standards was considered the most successful way to guarantee that local agents governed in the light of the order's overall interest. If local superiors had to have substantial leeway due to the distance and difference between Europe and Asia, their ongoing compliance with broader Jesuit goals set by Rome could best be ensured by focusing on their personal qualities. Moral integrity and administrative acumen would be the most effective barriers against the potential for abuse of geographical isolation.

Valignano returned to this point time and again. His argument was simple. Since the administrative situation in Asia was extraordinary, so too should superiors have extraordinary qualities:

Since the distance and the type of duties here make it impossible to wait for answers from Rome and since it is thus inescapable that the provincial will have to make important decisions on his own (even those that elsewhere are the sole responsibility of Father General) and since he thus has to have wide-ranging faculties (which are much more extensive than the faculties ever granted to European provincials) it follows that the Indian superior will require much more virtue, prudence and experience in matters of Jesuit governance than all other provincials. This is because he is so distant from the general and thus holds extraordinary powers. ${ }^{71}$

Securing personnel of the highest quality was a general concern for the Society of Jesus. Yet, according to the Jesuits from the Indian province, the best of the crop should always be deployed to Asia given the special challenges of governing in the region. Precisely what qualities were needed, however, was not always spelled out with sufficient clarity. Valignano was often vague in his

China. Brockey points out that due to the lack of personnel the Chinese missionaries usually lived isolated and without proper supervision by any superior at all.

71 Valignano, "Sumario," 561 : "Porque la distancia y los negocios no dan lugar a que se espere respuesta de Roma, y assi es necessario que el provincial por si mismo concluya cosas gravissimas que en todas las otras provincias san reservadas al padre general, y assi necessariamente ha-de tener facultad de hazer y mandar a su modo todos los superiores consultores etc. y de encorporar y escluyr los subjectos del cuerpo de la Compañia y fundar casas y colegios [etc....] y finalmente ha de tener mucho mayor y mas ampla facultad de todos los provinciales de Europa, de donde se sigue que ha-de tener mayor virtud, prudencia y experiencia de las cosas de la Compañia y de su govierno que los otros provinciales, porque esta tan lexos de su general y tiene una facultad tan suprema." 
comments, ${ }^{72}$ usually content to call for the "best" Jesuits who had "more" of every quality than those working in Europe or elsewhere. ${ }^{73}$

Occasionally, however, Asian Jesuits stated more clearly what was required of superiors in India. Antonio Marta was particularly explicit. Up to now, he said, higher education and university training had been considered unimportant for Jesuits working in Asia. ${ }^{74}$ Marta disagreed on the basis of his own "experience." Well-educated people (letrados) were in fact especially necessary in the Moluccas. Superiors here constantly had to "distinguish correctly between right and wrong, important and unimportant." This he considered an extraordinary challenge. Not least of all, education was necessary to know "when to dissimulate issues and when not." Such decisions had to be made every day by superiors in the Moluccas "because we are far from India and cannot always expect orders from there." If local superiors were personally incapable of making these decisions, however, "we are without guidance and people will say we are governed by those lacking experience and will lose confidence in us."75 Marta thus described much more clearly than Valignano what kind of decisions had to be taken and how Asian decision-making was particularly challenging and differed from decision-making in Europe and elsewhere.

Marta's description of decision-making in Asia would have sounded familiar to almost every Jesuit, wherever he lived. Distinguishing right and wrong, determining what best to do - this was clearly a reference to the most basic and typical Jesuit virtue: discernment (discretio or ż $\pi \varepsilon \varepsilon \dot{x} \varepsilon \varepsilon$ [ [epieikeia]). This was the virtue of correctly assessing specific circumstances, weighing the different alternative options, and choosing the course of action best suited to promote the spiritual goals of one's personal life or the entire order. Ignatius of Loyola had devoted considerable attention to this topic in his Spiritual Exercises.

72 Other Jesuits usually also produced only vague comments, e.g. Doc. Ind., 12:595 (Didacus de Cunha to Acquaviva, December 8, 1581).

73 See e.g. Doc. Ind., 14:610 (to Acquaviva, from Nagasaki, October 27, 1591). See also the statements concerning Japan in Valignano, Jésuites au Japon, 191-92. See Doc. Ind., 15: 280 (to Acquaviva, July 24, 1589).

74 In fact, St. Francis Xavier himself had held this view, Doc. Mal., 1:95. A position similar to Francis's e.g. in Doc. Ind., 14: 548 (Jerónimo Xavier, Rector in Cochin, to Acquaviva, January 2,1587 ).

75 Doc. Mal., 2:276: "Por saber diferentiar o ben do mal, o importante do leve, e o que se deve dissimular e o que não [...] E mais, assi como estamos aqui muito longe da India, hé mister que os Padres que aqui andão possão determinar da si e tirar a limpo as dificultades que acontecem, por não se poder esperar muitas vezes a reposta da India. Doutra maneira ficamos irresolutos e sim remedio, e a gente dize que Maluco hé governado de mancebos, e o que se faz não tem credito." 
Discernment had thus become deeply embedded within Jesuit identity. Every Jesuit should possess this virtue, yet, as Marta pointed out, officials governing in faraway lands, where guidance and surveillance by Rome was necessarily scarce, had greater need of it than others. Tapping into traditional Jesuit spirituality thus proved helpful in conceptualizing the personal requirements for Asian governance. Marta's allusion to Ignatian discretio specified, but also controlled and sanctioned his call for increased regional independence. And it significantly raised the spiritual bar for potential candidates. ${ }^{76}$

How to guarantee the quality of Jesuit personnel in Asia was an entirely different question - and a much more practical one. Valignano suggested that he himself should go back to Europe to select appropriate men. He did not trust the order's standard bureaucratic procedure of personnel selection. ${ }^{77}$ Other Asian Jesuits suggested the opposite and insisted that Rome alone should make the decision. Some expressed a degree of mistrust in regard to provincials in Portugal and Spain, who were suspected of withholding their best men from the missions. ${ }^{78}$ It should also be noted that the selection of personnel for the overseas missions occasionally became tainted by national antagonism. Portuguese Jesuits commonly mistrusted Italian or Spanish members of the order and vice versa. ${ }^{79}$

If the Jesuits' trust in personnel seems somewhat naïve, it nevertheless represents a serious attempt to solve a more general problem facing multi-local institutions. Valignano and his colleagues were very explicit that the careful selection of personnel would help mitigate the difficulties and dangers of governance in distant provinces such as India. They thought this a useful mechanism for calibrating the practical need for local autonomy with the ideological commitment to Rome as the unquestioned center of power in the order.

\section{Conclusion}

In 1593, Valignano summarized the situation for Acquaviva anew:

$7^{6}$ A reference to "epicheia" as necessary quality for Indian superiors can be found in Doc. Ind., 12:339 (Rui Vicente, Provincial, to Acquaviva, October 30, 1581).

77 See his very harsh criticism of the informationes ad gradum, invented only a few years earlier, in Doc. Ind., 13:742-45 (December 20, 1584, to Acquaviva).

78 E.g. Doc. Ind., 12:339.

79 Discussions are frequent, e.g. Doc. Ind., 12:439-40 (Valignano to Acquaviva, December 13, 1583). On the complex relationship of Valignano with Portugal and the Portuguese Jesuits see e.g. Üçerler, “Valignano," 340-44. 
Even though they [i.e., the Jesuits] in Japan are forced to accommodate to local circumstances and to local habits, and have to adjust their way of living and their offices according to the ways of this country, and though their perpetual peregrinations force them to adopt customs and methods of ministry not used in Europe, they nevertheless follow the same spirit [as all other Jesuits] and work for the same goal, that is the glory of God, their own salvation, and the salvation and betterment of the people. ${ }^{80}$

Adjusting to local circumstances without departing from the one "Jesuit way": these were the two pressing, albeit potentially contradictory, imperatives for Jesuits in Asia. This ambiguity did not only apply to religious and cultural matters but also - and one might say especially — to the domain of institutions, style of government, and power relations. Navigating between the Scylla of local autonomy and the Charybdis of all-out Roman centralization was as difficult as it was necessary for all early modern Jesuits. The dilemma posed itself everywhere in Jesuit governance, even in the relative vicinity of Rome. Indeed, the limits of central governance and the necessity for some degree of local agency have to be dealt with by all multi-locational social organizations, at all times. The problem, at its heart, is organizational, not infrastructural, although the available infrastructure certainly dictates the range of possible solutions and perhaps also the degree to which the problem makes itself apparent. There is no doubt that the unique infrastructural difficulties and the unusual cultural challenges of the early phases of globalization were particularly acute. Experiences in Asia certainly brought a degree of urgency to the larger questions of Jesuit governance.

It should have become clear by now that the unified and homogeneous vision of Jesuit administrative space offered by Francisco Suárez was entirely unrealistic. Distance and difference were the main reasons why institutional and administrative adjustments were necessary. Stressing the gap between Rome and Goa and between Goa and Ambon or Nagasaki, say, meant fragmenting the homogeneity of Jesuit administrative space. Asian Jesuits sought

$80 \quad$ Doc. Ind., 14:65 (January 1, 1593): "Y aunque por la qualidad y costumbres de la tierra, a los quales necesariamente son forçados acomodarse, y por los oficios y cargos que tienen de la conversión y christiandad de Japón, y por el modo de bivir, espargidos y solos en una continua peligrinación por las residencias, son forçados a tener otra manera de vida y otras ayudas y ministros que en Europa no tienen, todavía proceden con el mismo spíritu y pretenden el mismo fin a gloria de nuestro Señor, de la propria salvación y perfeción, y de la salvación y perfeción de los próximos." 
to put themselves on the order's administrative mental map by stressing the particularities of their situation. The fluid and nuanced concept of institutional uniformity that developed within the Society of Jesus as a consequence is remarkable. It would seem that Jesuits in India consciously distinguished between different degrees of adherence to the European model. If Asia in its entirety, even from the perspective of Jesuits in Asia, was a somewhat peripheral corner of the Jesuit world, there were nevertheless centers and peripheries within the periphery itself. Difference from and conformity to European standards were carefully calibrated along a sliding scale, even by Rome. ${ }^{81}$ The order's administrative blueprint became applicable on a global scale only by allowing for myriad variations.

It is important to note just how pragmatic and open to adjustments both Valignano in Asia and Acquaviva in Rome actually were. Jesuits in the Indian province tampered with the order's administrative framework on numerous occasions. They debated the role that Rome could play meaningfully in such far-away regions. And Rome, it needs to be highlighted, generally kept an open ear for such requests. A great deal of autonomy was granted and the Jesuit headquarters in Rome frequently granted requests for highly flexible applications of universal standards. On the rather rare occasion that the general attempted to micromanage Indian affairs, he was normally careful to acknowledge his limited knowledge and competence. ${ }^{82}$

Even the most basic assumptions about the Jesuits' administrative practices thus came under scrutiny. Indeed the idea of "lettered governance" itself was openly questioned, though never abandoned outright. Valignano and most other Asian Jesuits, when asking for more autonomy and an alteration of "normal" procedures, never considered adjustments as a critique of centralized governance as such. Though calling for substantial administrative changes, they presented their alternative ideas as approaches within the standard Jesuit

81 See especially Acquaviva to the Indian provincials, Doc. Ind., 12:687: At least the "principal" colleges in Goa and Cochin should comply more strictly to the European standards than those establishments further away.

82 An illustration is provided by Aquaviva's letter to Provincial Pedro Martins, January 12, 1589, in Doc. Ind., 15:246. Acquaviva discusses several points and voices his own preferences or concerns, but usually closes his statement with a limiting qualification such as "V.R. lo verá de más cerca y lo consulterá." It would appear that some of his requests were more symbolic than practical, meant to display more his interest in India than suggesting concrete paths of action, e.g.: "En el collegio de Goa se entiende ha avido muchos enfermos; deseo que se halle remedio. V.R. lo consulte allá." 


\section{system of governance. ${ }^{83}$ Consequently, the call from Asian Jesuits to modify Jesuit administrative practice was not considered by Rome to threaten the or- der's social coherence.}

83 At least occasionally, Asian Jesuits reflected on the implications of administrative pluralism for social and organizational unity; see Valignano's statement in Doc. Ind., 14:100-1: "Quanto a las tres puertas que escreví a V.P. que deseava mucho que se enserrassen para el bien y unión de la Compañía, scilicet, que hoviesse uniformidad en las opiniones de las sciencias y en la manera o espírito de orar, y en el modo de governar, no le escreví tanto por esta Provincia como por las otras, porque aunque en el modo de governar ha aquí diversidad de pareceres algunas vezes, todavía en lo que toca a la opinión en las letras ha mucha uniformidad, y en lo que toca a la manera de orar no ha aquí dicención, porque la tierra y los negocios naturalmente más nos llevan a la destración que a gastar demasiado tienpo en orar." See also his letter to Acquaviva (December 20, 1586) in Doc. Ind., 14:436-47, although from a somewhat more limited perspective. Significant is also Doc. Ind., 15:294-95, where he first defends his accommodation of rules to local circumstances and then sums up his work in these words: "Y después que ellos se hizieron, se vio claramente aver uniformidad en el govierno de la christianidad." 